\title{
ASPEK SUPERORDINAT DALAM RUANGAN POJOK AWANG SELAMAT
}

\author{
(SUPERORDINATE ASPECT IN AWANG SELAMAT'S COLUMN)
}

\author{
Tengku Shahrolnizam Tengku Yahya
}

stengku@ hotmail.com

\author{
Rohaidah Haron \\ eyda1826@um.edu.my
}

Akademi Pengajian Melayu, Universiti Malaya
Malaysia

Received: 11 Mac 2020; Accepted: 9 November 2020

\begin{abstract}
The cohesion aspect in the field of discourse analysis serves to connect one idea to another in a structured manner, thereby allowing the text to link well and in a way that is easily understood by readers. Hence, the cohesion aspect is vital in newspaper writing, specifically the editors' columns, because well-organised ideas can deliver the message to readers effectively. The superordinate is one of the elements of the cohesion aspect proposed by Halliday and Hasan (1976) which incorporates the component of vocabulary device or vocabulary cohesion. This study on superordinate aspects utilised the Awang Selamat article published in the Mingguan Malaysia newspaper dated $18^{\text {th }}$ September 2016. The objectives of this study are to identify the superordinate aspect in the editor's column and analyse the use of the superordinate in the said section. Findings showed that vocabulary cohesion aspect involving the use of superordinate existed in the texts and play an important role in forming an integrated and structured connection of meanings in data. The ability of an editor's column writer to make full use of the superordinate aspect allowed the Awang Selamat article to be easily understood and very appealing to read. It is hoped that this study on the superordinate aspect can be a guide for language researchers to understand the cohesion aspect in-depth, especially in the development of the field of discourse in the Malay language.
\end{abstract}

Key words: Discourse, cohesion, superordinate, editor's columns, lexical.

\begin{abstract}
Abstrak
Aspek kohesi yang terkandung dalam bidang analisis wacana berfungsi untuk menghubungkan satu idea dengan idea yang lain dengan teratur, selanjutnya menjadikan teks bertaut dengan baik dan difahami dengan mudah oleh pembaca. Oleh itu, aspek kohesi sangat penting dalam akhbar, khususnya ruangan pojok kerana idea yang teratur berupaya menyampaikan mesej kepada pembaca dengan berkesan. Superordinat merupakan satu daripada aspek kohesi yang dimajukan oleh Halliday dan Hasan (1976) yang merangkumi
\end{abstract}


komponen 'alatan leksikal' (vocabulary device) atau kohesi leksikal. Sehubungan dengan itu, kajian aspek superordinat ini memanfaatkan artikel Awang Selamat yang disiarkan dalam akhbar Mingguan Malaysia bertarikh 18 September 2016. Objektif kajian ini adalah untuk mengenal pasti aspek superordinat dalam ruangan pojok dan menganalisis superordinat dalam ruangan pojok. Hasil kajian mendapati aspek kohesi leksikal yang melibatkan superordinat wujud dalam teks dan memainkan peranan penting dalam membentuk jalinan makna yang bersepadu dan berstruktur dalam data. Keupayaan pengarang ruangan pojok memanfaatkan aspek superordinat menjadikan artikel Awang Selamat mudah difahami dan sangat menarik untuk dibaca. Kajian aspek superordinat ini diharapkan dapat memberi panduan kepada pengkaji bahasa untuk memahami aspek kohesi dengan lebih mendalam terutama dalam perkembangan bidang wacana bahasa Melayu.

Kata Kunci: wacana, kohesi, superordinat, ruangan pojok, leksikal.

\section{Pendahuluan}

Dalam bidang wacana, aspek kohesi merupakan aspek penting yang perlu diberi perhatian sewajarnya. Kohesi atau cohesion berkait rapat dengan unsur pemaut dan penyatu yang dapat menjadikan teks sebagai kalimat yang bermakna. Jika tiada kohesi dalam teks, sesuatu teks atau wacana tidak akan bertaut dengan baik kerana tiada jalinan idea yang dapat mempertaut teks menjadi suatu kalimat yang bermakna dan difahami oleh khalayak pembaca. Salah satu cara untuk mewujudkan kohesi dalam teks adalah dengan memanfaatkan penyataan semula leksikal atau reiteration. Menurut Halliday dan Hasan (1976, p. 278), reiteration didefinisikan sebagai:

Reiteration is a form of lexical cohesion which involves the repetition of a lexical item, at the other end of the scale; and a number of things in between - the use of a synonym, near-synonym or superordinate.

Berdasarkan konsep reiteration yang diperkenalkan oleh Halliday dan Hasan (1976), pernyataan semula leksikal merupakan unsur leksikal yang dapat mewujudkan tautan dalam teks, iaitu menerusi pemanfaatan unsur sinonim, hampir sinonim dan superordinat. Menurut Idris Aman (2010, p. 61), kohesi leksikal ialah alat pembina pautan yang penting kerana membawa maklumat atau idea dalam wacana. Oleh sebab pernyataan semula leksikal sangat penting dalam teks atau wacana, maka aspek ini akan diketengahkan dalam makalah ini bagi menjelaskan peranannya dalam mewujudkan tautan idea dalam wacana. Pernyataan semula leksikal sememangnya berfungsi untuk membentuk kohesi dalam teks, khususnya bagi mengelakkan kebosanan mengulang kata yang sama dalam teks. Dalam hal ini, pernyataan semula leksikal tidak boleh dianggap sebagai unsur lewah seperti pendapat sesetengah ahli bahasa yang mengaitkan lewah sebagai bentuk kesalahan struktur ayat. Sebaliknya, aspek kohesi berkaitan pernyataan semula leksikal bukanlah unsur lewah kerana pengarang menggunakannya dalam teks untuk mengelakkan pengulangan leksikal yang sama dan serta menimbulkan kreativiti dalam penulisannya (Noor Suraya Adnan Sallehudin, Sakina Suffian \& Kamila Ghazali, 2016, p. 90).

Penulis akan membataskan perbincangan dalam penulisan ini dengan memperincikan satu aspek dalam pernyataan semula leksikal, iaitu superordinat. Menurut Halliday dan Hasan (1976, p. 279), superordinat merupakan salah satu daripada aspek yang membentuk kohesi 
dalam teks, iaitu menerusi aspek rujukan (reference) dalam teori kohesi. Sebagai satu daripada aspek penting yang menentukan keberkesanan penyampaian sesuatu mesej dalam teks, penulis teks perlu menggunakan aspek superordinat dengan sebaiknya agar mesej yang hendak disampaikan seperti dalam ruangan pojok dapat difahami oleh khalayak pembaca. Sehubungan dengan itu, makalah ini bertujuan untuk mengenal pasti aspek superordinat dan menganalisis fungsi superordinat dengan memanfaatkan ruangan pojok Awang Selamat sebagai teks kajian.

\section{Teori Kohesi}

Teori kohesi yang diutarakan oleh Halliday dan Hasan (1976) menjadi panduan dalam kajian ini. Teori tersebut merangkumi komponen tekstual melalui 'alatan nahuan' (grammatical device) dan sebahagian lagi melalui 'alatan leksikal' (vocabulary device) dan kedua-duanya dari segi teori dinamakan kohesi nahuan dan kohesi leksikal. Menurut Halliday dan Hasan (1976), makna yang lebih umum diterangkan melalui kohesi nahuan, manakala makna yang lebih khusus diterangkan melalui kohesi leksikal.

Pengkaji seperti Halliday dan Hasan (1976, p. 29) telah menerangkan kohesi nahuan melalui empat kaedah utama, iaitu rujukan (reference), penggantian (substitution), penghilangan (ellipsis) dan penghubung (conjunction). Kohesi leksikal pula melibatkan pernyataan semula leksikal dan pemanfaatkan leksikal berkolokasi. Pernyataan semula leksikal ini berlaku dalam tiga cara iaitu, (i) pengulangan kata sama atau hampir sama, (ii) penggunaan kata sinonim atau hampir sinonim, dan (iii) penggunaan kata superordinat (yang melibatkan hiperonim) (Halliday \& Hasan, 1976, p. 278). Hal ini dapat digambarkan dalam rajah berikut, iaitu:

\footnotetext{
Pernyataan semula leksikal

Pengulangan kata sama atau hampir sama

Pengulangan kata sinonim atau hampir sinonim Kata superordinat
}

Kohesi leksikal ialah alatan pembinaan pautan yang penting kerana alatan inilah yang membawa maklumat atau idea dalam wacana. Dalam teori kohesi, aspek superordinat yang tercakup dalam kohesi leksikal dapat dikaitkan dengan tautan kerana fungsinya sebagai rujukan (reference). Menurut Halliday dan Hasan (1976, p. 33), kohesi berkaitan hubungan makna yang merujuk pada unsur sebelum atau selepas atau dikenali sebagai anafora atau katafora. Menurut Dictionary of Language Teaching and Applied Linguistic (2002, p. 25), anafora merujuk unsur yang telah diterangkan sebelumnya, manakala katafora ialah rujukan di hadapan yang berfungsi sebagai kohesi dalam ayat. Kedua-dua bentuk rujukan ini dapat membentuk kohesi dalam teks kerana aspek superordinat yang diaplikasikan dalam teks adalah bagi elemen yang hendak dikaitkan antara makna umum dan makna khusus. Hal ini secara tidak langsung dapat mempertaut teks menjadi idea yang saling berkesinambungan antara satu sama lain. Kedua-dua rujukan secara anafora dan katafora dikaitkan dengan aspek superordinat akan membantu menjadikan teks ruangan pojok menarik untuk dibaca terutamanya dari segi keupayaan pengarang memanfaatkan pelbagai kata umum bagi mewujudkan kohesi dengan kata yang lebih khusus. Oleh sebab ruangan pojok bersifat ringkas, maka mesej yang ingin disampaikan oleh pengarang mesti jelas dan mudah difahami 
oleh semua lapisan pembaca. Pada masa yang sama, penyampaian ayat demi ayat perlu jelas dan di sinilah aspek superordinat perlu diaplikasikan dengan sebaiknya oleh pengarang.

\section{Konsep Superordinat}

Pernyataan semula melalui kata superordinat merupakan satu daripada cara untuk membentuk kohesi dalam wacana. Superordinat merupakan kata yang maknanya terangkum dalam makna lain dan berfungsi sebagai rujukan. Halliday dan Hassan (1976, p. 278-279) memberi contoh berikut:

(i) Henry's bought himself a new Jaguar. He practically lives in the car.

Makna umum: $\quad$ car

(ii) There's a boy climbing that tree. The child's going to fall if he doesn't take care.

$\begin{array}{lc}\text { Makna umum: } & \text { child } \\ \text { Makna khusus: } & \text { boy }\end{array}$

Dalam contoh ayat (i), Halliday dan Hasan (1976) menjelaskan bahawa Jaguar adalah merujuk kereta (car). Dalam konteks ayat ini, kereta (car) merupakan superordinat kepada Jaguar. Hubungan antara Jaguar dan car dalam ayat ini sangat rapat dari aspek makna kerana keduanya berkohesi antara sata sama lain, iaitu car merupakan makna umum, manakala Jaguar membawa makna khusus. Begitu juga dengan ayat (ii) apabila perkataan child merupakan superordinat kepada boy. Dalam ayat ini child merupakan makna umum, manakala boy merupakan hiponim yang menunjukkan makna khusus. Aspek superordinat dalam ayat ini menunjukkan adanya unsur tautan apabila perkataan boy yang merujuk child serta merupakan rujukan secara katafora (to following text).

Menurut Idris Aman (2010, p. 63-64), kohesi leksikal menerusi kata superordinat melibatkan penggunaan kata yang lebih umum (hiperonim) dan kata yang juga kata yang lebih khusus (hiponim), misalnya negara ialah kata umum, manakala Malaysia ialah kata khusus, Barisan Nasional ialah kata umum, manakala UMNO, MCA, MIC, dan Gerakan merupakan makna khusus. Menurut Idris Aman (2010, p. 61), pernyataan semula leksikal menerusi superordinat merupakan alatan pembina pautan yang penting kerana alatan inilah yang membawa maklumat atau idea dalam wacana. Menurut Puteri Roslina Abdul Wahid (2005, p. 68), partitif ialah perkara yang penting dalam konsep superordinat kerana sesuatu ciri itu merupakan sebahagian daripada keseluruhan, misalnya basikal merupakan superordinat bagi tayar, rim, jejari dan hab. Menurut Dictionary of Language Teaching and Applied Linguistic (2002, p. 243), superordinate atau hyponymy ditakrifkan sebagai: 
Hyponymy is a relationship between two words, in which the meaning of one of the words includes the meaning of the other word. For example, in English the words animal and dog are related in such a way that dog refer to type of animal, and animal is a general term that includes dog and other type of animal. The specific term, dog, is called a hyponym, and the general term, animal, is called a superordinate. A superordinate term can have many hyponyms. For example:

superordinate:

hyponyms:

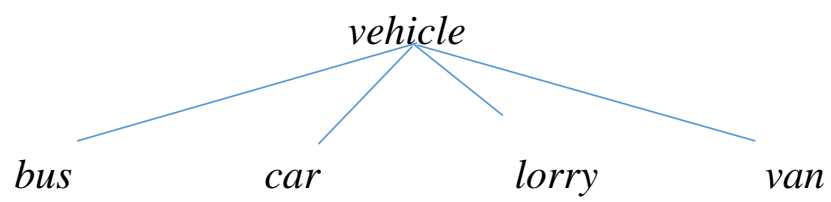

Dalam contoh yang dinyatakan oleh Dictionary of Language Teaching and Applied Linguistic (2002), vehicle merupakan bentuk superordinat, manakala bus, car, lorry dan van ialah hiponim yang menerangkan kategori kenderaan tersebut yang dikaitkan dengan makna khusus.

Dalam wacana, aspek superordinat yang diaplikasikan oleh pewacana adalah bertujuan untuk membuat klasifikasi terhadap konsep atau antara kelas generik dan spesifik. Menurut Kuswoyo (2019, p. 222) penyusunan klasifikasi dalam wacana dapat mengelompokkan bentuk ujaran yang secara semantik berbentuk umum (hiperonim) dan kemungkinan akan menjadi ujaran spesifik atau khusus (hiponim). Dengan adanya bentuk ujaran yang spesifik ini secara tidak langsung dapat memperluas makna ujaran dan seterusnya membawa maklumat atau idea dalam wacana. Daripada penjelasan tentang konsep superordinat, maka dapat disimpulkan bahawa superordinat memainkan peranan penting dalam membentuk kohesi teks. Kepelbagaian bentuk hiponim yang terdapat dalam teks dan dikaitkan dengan makna khusus menjadikan sesuatu teks atau wacana itu menarik untuk dibaca kerana pengarang dilihat berupaya memanfaatkan aspek kohesi leksikal. Pada masa yang sama, superordinat memberi pengetahuan yang mendalam kepada pembaca untuk mengetahui sesuatu isu dengan lebih terperinci.

\section{Sorotan Kajian}

Puteri Roslina Abdul Wahid dan Hasnah Mohamad (2010) dalam kajian yang bertajuk Terminografi Melayu: Kosa kata seni kraf Melayu telah memberi tumpuan terhadap penggubalan istilah baharu berdasarkan konsep yang dibina bagi menyediakan glosari atau kamus teknikal. Kajian ini berkaitan terminografi yang berhubungan rapat dengan leksikografi. Ahli leksikografi mendokumenkan kata dalam perbendaharaan kata umum, manakala ahli terminografi mendokumenkan istilah khusus dalam bidang, domain atau disiplin khas dan dilihat mempunyai perkaitan dengan konsep superordinat. Terminografi dalam seni kraf tangan Melayu dapat dilihat dalam contoh entri canting, yang membawa makna umum, manakala pemegang, mata dan kepala merupakan makna khusus. Hubungan yang wujud antara makna umum dan makna khusus juga dikenali sebagai hubungan partitif atau seluruh-bahagian. Dalam aspek kohesi, aspek ini dikenali sebagai superordinat. 
Eva Amalijah (2014) telah mengkaji aspek superordinat dalam kajiannya yang bertajuk Hubungan antara hiponim dengan entailment dalam bahasa Jepang. Kajian ini menjelaskan hubungan antara superordinat atau hiponim dengan entailment yang memiliki hubungan dalam penyampaian makna yang paralel atau selari. Menerusi kajian ini, makna yang terkandung dalam hiponim juga hadir dalam entailment. Sehubungan dengan itu, kajian ini dilakukan bagi melihat hubungan yang wujud antara hiponim dengan entailment dalam bahasa Jepun. Hiponim melibatkan hubungan khusus dengan makna lain, manakala entailment ialah pertalian yang bersifat mutlak. Dalam hiponim, klasifikasi terhadap konsep sesuatu perkataan dijelaskan menerusi maksud spesifik dan maksud generik. Sebagai contoh, merpati dan terkukur ialah nama spesifik bagi kelas generik burung. Bagi entailment pula, pertalian yang bersifat mutlak dapat diperhatikan menerusi simbol (+) dan (-). Sebagai contoh, +Ali membunuh Jon. -Jon Mati. Dalam contoh ini, hubungan antara Ali dan Jon bersifat entailment kerana Jon mati akibat dibunuh oleh Ali. Secara kesimpulannya, kajian ini menjelaskan bahawa hiponim dan entailment mempunyai hubungan makna yang sejajar kerana makna yang terdapat pada hiponim juga terdapat pada entailment.

Kajian oleh M. Supriyanto Wahyu U. (2014) yang bertajuk Kajian semantik penggunaan hiponim dan hipernim pada judul wacana dalam Koran Kompas edisi September - Oktober 2013 juga mengkaji berkaitan aspek superordinat. Kajian ini bertujuan untuk mengetahui penggunaan dan fungsi penggunaan hiponim dan hipernim secara keseluruhan dalam wacana Koran Kompas. Hasil kajian ini mendapati terdapat dua kata bentuk hiponim dan hiperonim, iaitu kata benda dan kata sifat. Data yang diperoleh setelah digolongkan berkait dengan bentuk nama. Bentuk nama tersebut meliputi dari nama negara, penyanyi pop asal Amerika, politikus, partai politik, mata wang, kota, bahan bakar minyak, pesawat atau maskapai penerbangan, warna, presiden, atlet sepak bola, narkoba, klub sepak bola, hasil perkebunan, provinsi, group band Indonesia, makanan gorengan, lauk pauk, pebalap, merk telefon genggam, merk arloji, dan produk makanan. Judul wacana yang terdapat pada KoranKompas juga menggunakan makna hipernim dan hiponim sehingga pembaca lebih mudah untuk menentukan objek yang ada pada wacana tersebut. Judul wacana pada KoranKompas menggunakan hiponim dan hipernim untuk menjelaskan objek yang akan dibahas, iaitu makna hipernim dan hiponimi juga digunakan dalam kehidupan sehari-hari.

Kajian oleh Noor Suraya Adnan Sallehudin, Sakina Suffian \& Kamila Ghazali (2016) yang bertajuk Kata Lewah dalam Hikayat Hang Tuah turut menyentuh aspek kohesi. Dengan mengaplikasikan teori kohesi yang dimajukan oleh Halliday dan Hassan (1976), kajian ini memberi fokus terhadap kata lewah dalam Hikayat Hang Tuah yang mempunyai kaitan dengan aspek kohesi, khususnya kohesi leksikal. Kajian ini memberi tumpuan terhadap hiperonim, hiponim, fonestema, bahasa figuratif dan kolokasi. Kajian ini memperlihatkan unsur lewah dalam karya agung Melayu bukannya sesuatu yang negatif, tetapi harus dipuji kerana menggambarkan kehebatan dan ketinggian akal budi serta pemikiran masyarakat Melayu pada zaman dahulu. Kajian ini memberi faedah dalam usaha mengangkat kembali perbendaharaan kata sebagai warisan bangsa. Kajian ini turut menerbitkan kata-kata yang telah hilang daripada kosa kata penutur asli bahasa Melayu dan dihidupkan semula untuk kegunaan orang ramai.

Dalam kajian yang dilakukan oleh Effendy Yusuff, Anida Sarudin dan Norliza Jamaluddin (2018) yang bertajuk Analisis makna leksis Singkowoton menggunakan pendekatan semantik ranah bersumberkan data korpus bahasa Melayu, ketepatan takrif makna sesuatu kata dikatakan berhubung kait dengan kebudayaan sesuatu masyarakat. Kajian ini berpandukan data korpus, leksis singkowoton yang memiliki makna teras yang bermaksud 
tengkorak manusia yang telah dipenggal. Walaupun kajian ini memfokuskan analisis makna leksis, namun elemen superordinat turut terangkum dalam kajian ini. Hasil analisis yang dijalankan menunjukkan bahawa singkowoton berkaitan makna umum, manakala makna khusus atau elemen ranah ialah benda dan kepercayaan. Kajian ini menyimpulkan bahawa leksis bahasa sukuan dalam korpus bahasa Melayu dapat diperincikan dengan melibatkan aspek leksikal, sosiobudaya dan pemikiran masyarakat.

Kuswoyo (2019) dalam kajiannya bertajuk Relasi hiponim (Isytimal) subordinat dan superordinat dalam semantik leksikografi telah membincangkan hubungan makna antara hipernim sebagai makna umum dengan hiponim sebagai makna khusus yang saling berhubungan kerana kedua-duanya bersifat searah. Kajian ini menunjukkan bahawa hiponim akan menjadi hipernim apabila ditemui makna yang lebih khusus daripada hiponim dan begitulah seterusnya. Hubungan antara leksem-leksem yang merupakan hiponim dengan leksem yang memayunginya (leksem inilah yang biasanya diistilahkan sebagai superordinat) disebut dengan hiponimi, sementara hubungan antara leksem yang satu dengan leksem yang lain yang sama-sama sebagai hiponim disebut sebagai kohiponim. Sebutan mawar, melati, dahlia, dan sejenisnya ialah hiponim dari bunga dan bunga merupakan superordinat atau hipernim dari mawar, dahlia, melati, dan sebagainya.

Seterusnya, kajian Siti Farida Salleh et.al (2020) dalam kajian yang bertajuk Analisis semantik leksikal dalam novel Sangkar karya Samsiah Mohd. Nor turut menyentuh aspek superordinat. Kajian yang berbentuk kuantitiatif ini mengaplikasi pendekatan semantik leksikal ini dengan memfokus jenis leksikal kepada sinonim, antonim, hiponim, polisim, homonim, homofon, homograf, metonim dan meronim yang terdapat dalam novel tersebut. Dalam novel Sangkar ini memperlihatkan penggunaan hiponim bagi haiwan yang paling banyak iaitu haiwan seperti serigala, cengkerik, kura-kura, burung, arnab, nyamuk, gajah, ayam, itik, buaya, ikan, unggas, udang, harimau, dan kambing. Selain itu, kelompok hiponim yang mempunyai jumlah kekerapan kedua tinggi ialah kelompok hiponim kepada kata warna yang berjumlah $43(24.67 \%)$ daripada jumlah keseluruhan. Seterusnya, kelompok hiponim yang menduduki jumlah kekerapan ketiga yang tertinggi ialah kelompok hiponim bagi kata kenderaan: kereta, van, motosikal dan bas yang berjumlah 28 (10.06\%) daripada jumlah keseluruhan. Akhir sekali, kelompok hiponim yang mempunyai jumlah kekerapan yang paling rendah dalam novel ini ialah kelompok hiponim bagi bunga yang mencatatkan jumlah kekerapan sebanyak 8 (4.56\%).

\section{Objektif Kajian}

Objektif kajian ini adalah untuk:

i. Mengenal pasti aspek superordinat dalam ruangan pojok Awang Selamat.

ii. Menganalisis aspek superordinat dalam ruangan pojok Awang Selamat.

\section{Metodologi Kajian}

Kaedah kajian teks bersifat deskriptif diaplikasikan untuk mengkaji kohesi dalam ruangan pojok yang diterbitkan dalam akhbar. Teknik kajian teks merupakan teknik terpenting dalam penyelidikan kualitatif yang mendasari aspek pengumpulan data. Kaedah ini sesuai diterapkan dalam kajian ini terutama bagi menganalisis data tentang kohesi yang terdapat dalam teks ruangan pojok Awang Selamat. Ruangan pojok Awang Selamat yang dipilih ialah 
teks yang diterbitkan dalam akhbar Mingguan Malaysia bertarikh 18 September 2016. Kajian kohesi memerlukan penelitian terhadap teks yang dipilih supaya menepati objektif kajian yang telah ditetapkan. Kajian ini bertujuan mengenal pasti unsur kohesi, iaitu aspek superordinat yang terdapat dalam wacana akhbar khususnya ruangan pojok. Sehubungan dengan itu, pengkaji telah memilih teks ruangan pojok Awang Selamat yang disiarkan dalam akhbar Mingguan Malaysia sebagai data kajian. Berikut merupakan kaedah pengumpulan data dalam kajian ini, iaitu:

(i) Pemilihan ruangan

(ii) Pembacaan terhadap teks

(iii) Proses analisis data

Kajian aspek kohesi dimulakan dengan pemilihan ruangan dalam surat khabar Mingguan Malaysia. Ruangan yang dipilih untuk kajian ini ialah ruangan rencana pengarang, iaitu ruangan pojok Awang Selamat. Teks ruangan pojok Awang Selamat dipilih kerana teks ini merupakan rencana pengarang yang popular dan telah diterbitkan sejak lima dekad yang lalu. Teks ruangan pojok Awang Selamat merupakan ringkasan berita yang memaparkan kritikan, komen dan pendapat bernas tentang isu-isu semasa baik dari dalam negeri mahupun luar negeri. Setelah menetapkan ruangan yang akan dikaji, langkah seterusnya ialah pengkaji membaca teks atau data yang telah dipilih bagi mendapatkan maklumat tentang superordinat. Proses ini melibatkan analisis terhadap teks ruangan pojok Awang Selamat untuk mengenal pasti aspek superordinat. Analisis dilakukan berpandukan konsep superordinat yang dijelaskan oleh Halliday dan Hasan (1976).

\section{Bahan Kajian}

Kajian aspek superordinat ini memanfaatkan teks ruangan pojok Awang Selamat yang diterbitkan pada 18 September 2016 sebagai bahan kajian. Ruangan pojok Awang Selamat merupakan catatan, pandangan dan kritikan yang ringan berkaitan isu semasa dan diterbitkan dalam ahkbar Mingguan Malaysia. Ruangan ini telah memainkan peranan yang sangat penting sejak sekian lama dan telah menarik perhatian pembaca di negara ini terhadap isu-isu politik, sosial dan agama dari semasa ke semasa, sama ada di dalam mahupun di luar negeri. Menurut Zam (1994), ruangan pojok Awang Selamat telah memberi sumbangan besar dalam mempengaruhi pendapat umum dan juga membentuk pemikiran rakyat menerusi perbincangan yang menggunakan logik yang mudah dan penonjolan realiti sebenar yang meyakinkan.

Walaupun penulis ruangan pojok Awang Selamat silih berganti sejak tahun 1967, namun matlamat asalnya tidak pernah berubah sehinggalah hari ini. Malah, ada ketikanya sesuatu isu yang dibicarakan dalam ruangan Awang Selamat itu menimbulkan perasaan kurang senang kepada pembaca (Zam, 1994). Menurut Zam (1994) apabila Mazlan Nordin mengambil alih jawatan Ketua Pengarang Kumpulan Utusan Melayu daripada Melan Abdullah pada tahun 1973, beliau telah mengekalkan Awang Selamat sebagai nama penulis pojok Utusan Malaysia dan Mingguan Malaysia. Nama Awang Selamat telah diberikan oleh Melan bagi menggantikan nama Awang Bungsu yang digunakannya di Utusan Malaysia sejak diterbitkan pada 1 September 1967. Zainudin Maidin telah mengekalkan nama ini apabila beliau mengambil alih jawatan Ketua Pengarang Utusan Melayu pada tahun 1983 daripada Mazlan Nordin. Tulisan Awang Selamat dari tahun 1987 hingga 1992 terutama sekali dalam Mingguan Malaysia banyak menimbulkan kontroversi terutama sekali daripada 
aspek agama dan sosial yang menampakkan sikapnya yang pragmatik, liberal dan tidak ada toleransi terhadap dogmatisme agama, komunis, kekolotan dan kekarutan (Zam, 1994).

Sehubungan dengan itu, bahan kajian yang dipilih ialah artikel dalam ruangan pojok Awang Selamat yang diterbitkan pada 18 September 2016. Artikel yang bertajuk Liabiliti? ini memaparkan kritikan terhadap bekas Perdana Menteri Tun Dr. Mahathir yang telah menyertai blok pembangkang dengan menubuhkan parti baharu. Bersesuaian dengan takrifan ruangan pojok yang merupakan kritikan dan komentar ringkas, maka pemanfaatan aspek superordinat yang terdapat dalam wacana ini menarik untuk dikaji memandangkan tautan idea yang jelas yang dikemukakan oleh pewacana telah menjadikan mesej yang hendak disampaikan bertaut dengan baik.

\section{Dapatan dan Perbincangan}

Dalam ruangan pojok Awang Selamat bertarikh 18 September 2016 yang bertajuk Liabiliti? pengkaji mendapati bahawa pewacana telah mengaplikasikan aspek superordinat dengan sewajarnya dalam teks. Pengaplikasian aspek superordinat tersebut bukan sahaja berupaya mewujudkan kefahaman yang baik kepada khalayak, tetapi memberi kesan yang menarik penulisan ruangan pojok tersebut. Hal ini bersesuaian dengan definisi ruangan pojok yang bermaksud ruangan dalam akhbar yang memuatkan kata-kata lucu tetapi pedas serta menyindir atau karangan pendek di sudut akhbar. Oleh sebab ruangan pojok merupakan karangan pendek yang dimuatkan dalam akhbar, maka pewacana harus berupaya memanfaatkan aspek superordinat sebaik mungkin agar pembaca memperoleh maklumat yang tepat, padat serta terperinci. Sehubungan dengan itu, pemanfaatan aspek superordinat penting dalam wacana kerana peranannya sebagai unsur pemaut yang membawa maklumat dalam wacana. Berikut dibincangkan aspek superordinat yang wujud dalam ruangan pojok Awang Selamat.

1. Seperti yang dijangka, penyerahan Deklarasi Rakyat oleh Dr. Mahathir Mohamad kepada Yang di-Pertuan Agong di Istana Anak Bukit, Alor Setar kelmarin tidak memberi impak.

\section{Makna umum: $\quad$ Alor Setar \\ Makna khusus: $\quad$ Istana Anak Bukit}

Berdasarkan data 1, hubungan antara makna umum dengan makna khusus dikenal pasti menerusi kata nama khas Alor Setar dan Istana Anak Bukit. Aspek kohesi wujud apabila Alor Setar yang merupakan kata nama khas menjadi rujukan di belakang atau katafora kepada Istana Anak Bukit yang hadir sebelumnya. Pengaplikasian aspek kohesi superordinat dalam ruangan pojok Awang Selamat ini secara tidak langsung menjadikan teks bertaut dengan baik kerana penyampaian makna umum sesuatu perkataan diperkembangkan menerusi makna khusus yang dapat menjadikan teks tersebut menarik untuk dibaca.

2. Hal ini kerana kegagalan deklarasi tersebut sebelum ini dalam menarik sokongan rakyat selain isu ketulenan 1.4 juta tandatangan. 
Makna umum:

Makna khusus: deklarasi

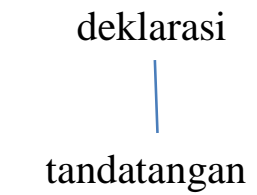

tandatangan

Berdasarkan data 2, contoh aspek superordinat yang dimanfaatkan oleh pewacana ialah kata nama deklarasi. Menurut Kamus Dewan Edisi Keempat (2016, p. 329), kata nama deklarasi merujuk pernyataan yang ringkas dan jelas tentang sesuatu. Oleh sebab perkataan ini mempunyai maksud yang umum, maka untuk mempertautkannya dengan idea lain yang lebih khusus, maka unsur hiponim akan dinyatakan dalam teks sebagai rujukan. Dalam wacana, rujukan merupakan satu daripada aspek kohesi yang berfungsi untuk mempertaut teks. Berdasarkan data 2, pewacana telah menggembleng kata tandatangan sebagai hiponim atau maksud khusus bagi deklarasi. Hal ini secara tidak langsung dapat memberi maklumat kepada pembaca bahawa kata tandatangan merupakan sebahagian maklumat khusus yang terdapat dalam maklumat umum atau menjadi superordinat kepada kata deklarasi. Pemanfaatan aspek superordinat ini menunjukkan bahawa sesuatu kata yang diaplikasikan dalam wacana mempunyai hubungan antara penggolongan dengan anggotanya. Sehubungan dengan itu, pengaplikasian kata deklarasi sebagai superordinat kepada kata tandatangan secara tidak langsung dapat mempertaut mesej yang hendak disampaikan dengan jelas terutama kepada pembaca. Hal ini demikian kerana secara lazimnya apabila kata deklarasi dimanfaatkan sudah tentu unsur hiponim kata tandatangan akan dikaitkan dengan kata deklarasi kerana kata tandatangan bertindak sebagai rujukan kepada hiperonim tersebut. Dalam konteks wacana ruangan pojok, penggemblengan aspek superordinat ini perlu dimanfaatkan sebaiknya oleh pewacana memandangkan ruangan pojok merupakan tulisantulisan pendek yang bersifat komentar dan pemanfaatan unsur ini secara tidak langsung memberi pemahaman yang lebih jelas kepada pembaca untuk memahami mesej yang hendak disampaikan.

3. Awang menjunjung kasih ke atas Tuanku Abdul Halim kerana memperkenankan Dr. Mahathir mengadap. Ternyata dakwaan beliau kononnya Yang di-Pertuan Agong dikenakan tahanan di istana adalah tidak benar.

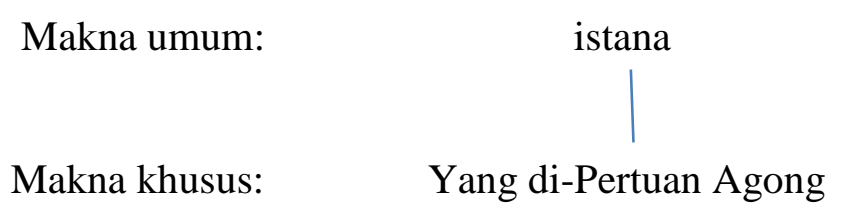

Berikutnya, aspek superordinat yang diaplikasikan oleh pewacana juga wujud menerusi makna umum kata istana yang dikenal pasti dalam data 3. Dalam data ini, kata istana yang merupakan makna umum berfungsi sebagai rujukan di belakang atau secara anafora bagi menerangkan makna khusus Yang di-Pertuan Agong. Bagi data 3, istana merupakan bentuk superordinat, manakala Yang di-Pertuan Agong merupakan hiponim yang dikaitkan dengan makna khusus istana. Menurut Kamus Dewan Edisi Keempat (2016, p.591), kata nama istana bermaksud rumah kediaman raja atau ketua negara. Oleh itu, penggunaan kata nama Yang di-Pertuan Agong bagi merujuk istana membuktikan aspek rujukan dalam superordinat berperanan membentuk kohesi dalam teks. Apabila pewacana memanfaatkan rujukan secara anafora, pembaca dapat melihat satu tautan idea yang kemas terutama dalam usaha pengarang ruangan pojok mengemukakan ideanya yang saling berkaitan antara satu sama lain. 
4. Perkembangan tersebut menyerlahkan Dr. Mahathir makin tertekan dan terdesak, yang sifat itu tidak seharusnya ada pada pemimpin besar. Jika mantan Pengerusi Barisan Nasional dan UMNO itu sanggup berbaik dengan musuh politik seperti Anwar dan Lim Kit Siang, tidak mengejutkan suatu hari nanti beliau akan kembali mendampingi Perdana Menteri, Najib Tun Razak.

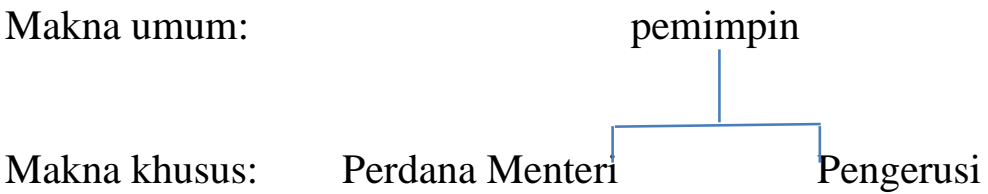

Selain itu, data 4 turut mengandungi aspek superordinat dalam wacana ruangan pojok. Dalam data ini, hubungan makna antara superordinat dengan hiponim dilihat dalam hubungan hierarki yang mengandungi komponen makna kata yang lain. Sebagai contoh, menerusi data 4, kata nama pemimpin merupakan superordinat atau makna umum, manakala Perdana Menteri dan Pengerusi ialah makna khusus. Hal ini demikian kerana seseorang Perdana Menteri ialah seorang pemimpin, manakala Pengerusi pula ialah ketua dalam mesyuarat, pemimpin jawatankuasa pertubuhan dan sebagainya yang juga seorang pemimpin. Oleh itu, kedua-dua hiponim tersebut sangat tepat untuk dikaitkan dengan makna umum. Dalam ruangan pojok Awang Selamat ini, pewacana memanfaatkan aspek superordinat sebagai satu daripada cara untuk membentuk kohesi dalam teks. Sebagai ruangan yang diminati ramai, maka aspek tautan seperti superordinat perlu diaplikasikan dalam wacana agar idea yang digarap dalam wacana dapat dihubungkan dengan teratur, selanjutnya menjadikan teks bertaut dengan baik dan mudah difahami oleh pembaca.

5. Semua orang tahu, gerakan untuk menggugat kerajaan dan menjatuhkan Najib di luar proses demokrasi tidak akan memberi kesan. Buktinya, satu demi satu percaturan Dr. Mahathir setakat ini tidak menjadi, malah menyebabkan beliau makin merudum pengaruh, sokongan dan simpati. Inilah yang berlaku apabila pemimpin hilang elegan dalam pendekatannya. Nasihat insan kerdil seperti Awang, memandangkan Dr. Mahathir telah menubuhkan parti politik baharu, eloklah beliau secara budiman menanti persaingan pada pilihan raya umum akan datang.

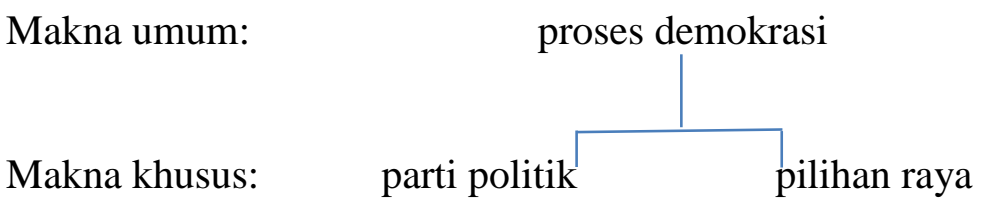

Aspek superordinat sebagai rujukan dalam membentuk kohesi dalam wacana juga dapat diteliti menerusi data 5. Sebagai makna umum dan makna khusus, aspek superordinat dalam data ini dapat dikenal pasti menerusi frasa proses demokrasi. Sebagai makna umum, pewacana perlu mempertaut idea tersebut dengan mengemukakan makna khusus agar pembaca ruangan pojok dapat memahami mesej yang hendak disampaikan. Umum mengetahui bahawa frasa nama proses demokrasi merupakan makna umum dan frasa tersebut dapat difahami menerusi hubungan hierarki dalam makna khusus seperti parti politik dan pilihan raya. Hal ini demikian kerana dalam negara yang mengamalkan proses demokrasi, rakyat dibenarkan menubuhkan parti politik dan bertanding dalam pilihan raya berbanding dengan negara yang mengamalkan autokrasi atau komunisme, pilihan raya dan parti politik 
tidak dibenarkan. Perkara ini secara tidak langsung mewujudkan hubungan hierarki antara makna umum dengan makna khusus. Pengaplikasian aspek superordinat ini menjadikan teks yang terhasil padat dengan mesej walaupun ruangan pojok hanya karangan pendek. Dengan adanya hiponim tersebut yang menjadi sebahagian komponen superordinat, maka mesej yang hendak disampaikan menerusi wacana ruangan pojok berupaya untuk difahami oleh pembaca.

6. Perkembangan tersebut menyerlahkan Dr. Mahathir makin tertekan dan terdesak, yang sifat itu tidak seharusnya ada pada pemimpin besar. Jika mantan Pengerusi Barisan Nasional dan UMNO itu sanggup berbaik dengan musuh politik seperti Anwar dan Lim Kit Siang, tidak mengejutkan suatu hari nanti beliau akan kembali mendampingi Perdana Menteri, Najib Tun Razak.

\begin{tabular}{ll|l} 
Makna umum: & musuh politik Dr. Mahathir \\
Makna khusus: Anwar & Lim Kit Siang
\end{tabular}

Di samping itu, aspek superordinat juga wujud dalam data 6. Menerusi data ini, tautan idea yang ingin disampaikan oleh pewacana dapat dikenal pasti dengan penggemblengan musuh politik Dr Mahathir sebagai aspek superordinat atau makna umum. Sebagai makna umum, pewacana telah mempertautkan makna tersebut dengan menghubungkannya kepada makna yang lebih khusus. Dalam hal ini Anwar dan Lim Kit Siang telah dikenal pasti sebagai hiponim atau makna khusus untuk dikaitkan dengan superordinat musuh politik Dr. Mahathir. Dalam politik Malaysia, umum mengetahui bahawa Anwar dan Lim Kit Siang telah menjadi musuh politik Dr. Mahathir sejak sekian lama. Anwar telah dipecat oleh Dr. Mahathir semasa menjadi Timbalan Perdana Menteri pada tahun 1998, manakala perjuangan parti DAP yang tidak sealiran dengan perjuangan Dr. Mahathir menyebabkan Lim Kit Siang terkenal sebagai musuh politik Dr. Mahathir. Usaha pewacana menggembleng aspek superordinat dalam data 6 secara tidak langsung mewujudkan kohesi dalam wacana ini apabila pembaca memperoleh maklumat dengan lebih jelas dengan penerangan makna khusus tentang musuh politik Dr Mahathir, iaitu Anwar dan Lim Kit Siang.

Makna umum: $\quad$ Dr. Mahathir

Makna khusus: pemimpin besar mantan Pengerusi Barisan Nasional dan UMNO

Dalam data 6 juga, aspek superordinat turut dikenal pasti menerusi makna umum kata nama khas Dr. Mahathir. Pewacana memanfaatkan makna umum Dr. Mahathir untuk mewujudkan kohesi dalam teks dengan mempertaut aspek superordinat tersebut dengan makna khusus pemimpin besar dan mantan Pengerusi Barisan Nasional dan UMNO. Dalam konteks data ini, kata nama khas Dr. Mahathir mempunyai komponen makna khusus lain yang dijelaskan menerusi hubungan hierarki dengan makna khusus seperti pemimpin besar dan mantan Pengerusi Barisan Nasional dan UMNO. Sebagai bekas pemimpin negara yang pernah menerajui Malaysia selama 22 tahun, sememangnya tepat apabila Dr. Mahathir dikaitkan dengan hiponim pemimpin besar. Sepanjang tempoh pentadbirannya sebagai Perdana Menteri keempat, Dr. Mahathir telah dikenali di seluruh dunia terutama dalam kalangan negara Islam. Oleh itu, apabila pewacana menjelaskan makna khusus Dr. Mahathir sebagai pemimpin besar secara tidak langsung mewujudkan tautan idea yang jelas antara 
superordinat dengan hiponim. Selain dikenali sebagai pemimpin besar, kata nama khas $D r$. Mahathir juga dijelaskan menerusi makna khusus sebagai mantan Pengerusi Barisan Nasional dan UMNO. Dalam aspek kohesi dalam wacana, penggemblengan unsur hiponim pemimpin besar dan mantan Pengerusi Barisan Nasional dan UMNO juga membentuk tautan dalam teks kerana kedua-dua hiponim tersebut merupakan rujukan bagi superordinat kata nama khas Dr. Mahathir.

\section{Kesimpulan}

Pernyataan semula leksikal melalui kata superordinat merupakan salah satu cara untuk membentuk kohesi dalam teks. Bertitik tolak daripada konsep superordinat yang diperkenalkan oleh Halliday dan Hasan (1976), maka pengaplikasian aspek ini dalam ruangan pojok Awang Selamat telah membantu untuk mewujudkan tautan idea dengan tersusun dan pada masa yang sama memberi pemahaman yang jelas kepada pembaca untuk memahami mesej yang hendak disampaikan oleh pengarang. Berdasarkan perbincangan ini, dapat dirumuskan bahawa kohesi leksikal yang melibatkan penggunaan kata superordinat mempunyai fungsi yang amat signifikan dalam teks. Sebagai teks yang menggembleng bahasa yang mudah serta ringkas, pengarang ruangan pojok Awang Selamat dilihat berupaya untuk memanfaatkan aspek kohesi dengan baik sekali dalam menyampaikan maklumat kepada pembaca. Keupayaan pengarang mengaitkan teks dengan unsur hiponim telah menjadikan artikel tersebut bertaut dengan baik sekali terutama antara ayat dengan ayat. Berdasarkan penelitian dan analisis aspek superordinat dalam ruangan pojok Awang Selamat, maka dapat dapat dirumuskan bahawa pengarang telah menghasilkan satu penulisan yang menarik dan mudah untuk difahami oleh khalayak pembaca. Hal ini disebabkan pengarang bijak memanfaatkan aspek superordinat yang bersifat umum dengan unsur hiponim yang bersifat khusus. Pemanfaatan aspek superordinat perlu diaplikasikan oleh pengarang dalam ruangan pojok Awang Selamat memandangkan ruangan pojok merupakan ruangan komentar ringkas yang memerlukan penggunaan bahasa yang jelas dan tepat.

\section{Rujukan}

Dictionary of Language Teaching and Applied Linguistic. (2002). Essex: Longman.

Effendy Yusuff, Anida Sarudin dan Norliza Jamaluddin. (2018). Analisis makna leksis Singkowoton menggunakan pendekatan semantik ranah bersumberkan data korpus bahasa Melayu, Jurnal Pengajian Melayu/Journal of Malay Studies (JOMAS), 29, 1-24.

Eva Amalijah. (2014). Hubungan antara hiponim dengan entailment dalam bahasa Jepang. Journal of Lingusitics, Literature and Cultural Studies, 14, 73-7.

Halliday, M.A.K. \& Ruqaiya Hasan. (1976). Cohesion in English. London: Longman.

Idris Aman. (2010). Analisis wacana. Bangi: Penerbit Universiti Kebangsaan Malaysia.

Kamus Dewan Edisi Keempat. (2016). Kuala Lumpur: Dewan Bahasa dan Pustaka.

Kuswoyo. (2019). Relasi hiponim (Isytimal) subordinat dan superordinat dalam semantik leksikografi. Jurnal Studi Agama, 7, 219-226. 
M. Supriyanto Wahyu U. (2014). Kajian semantik penggunaan hiponim dan hipernim pada judul wacana dalam Koran Kompas edisi September - Oktober 2013. Tesis Sarjana. Fakultas Keguruan dan Ilmu Pendidikan. Surakarta: Universitas Muhammadiyah Surakarta.

Noor Suraya Adnan Sallehudin, Sakina Suffian \& Kamila Ghazali. (2016). Kata lewah dalam hikayat Hang Tuah. Idris Aman \& Kamila Ghazali, Praktis analisis wacana. Kuala Lumpur: Penerbit Universiti Malaya, pp. 71-91.

Puteri Roslina Abdul Wahid. (2005). Definisi dan konteks dalam terminologi bahasa Melayu. Jurnal Pengajian Melayu/Journal of Malay Studies (JOMAS), 16, 68.

Puteri Roslina Abdul Wahid \& Hasnah Mohamad. (2010). Terminografi Melayu: Kosa kata seni kraf Melayu. Jurnal Pengajian Melayu/Journal of Malay Studies (JOMAS), 21, 212-225.

Siti Farida Salleh, Yazid Yahya, Mary Fatimah Subet \& Muhammad Zaid Daud. (2020). Analisis semantik leksikal dalam novel Sangkar karya Samsiah Mohd. Nor. Asian People Jurnal, 3(1), 45-63.

Zam. (1994). Yang terbaik daripada Awang Selamat koleksi pilihan 1987-1992. Kuala Lumpur: Utusan Publication \& Distributors Sdn.Bhd. 